\title{
'A Good Shelleyan': I
}

\author{
T. J. WISE
}

From Doris Arthur Jones, The Life and Letters of Henry Arthur Jones (London: Victor Gollancz, 1930) p. 221. Shaw's provocative declaration that he was 'like Shelley, a Socialist, Atheist and Vegetarian' (see Sixteen Self Sketches [London: Constable, 1949] p. 58) was made at the first regular meeting of the Shelley Society on 14 April 1886. In his own recollection Shaw claimed that two of the pious old ladies' whose subscriptions kept Furnivall's literary societies going were so scandalised by his speech that they 'resigned on the spot' ('Notes by George Bernard Shaw', Appendix I in Wilfred Partington, Thomas J. Wise in the Original Cloth [London: Robert Hale, 1946] pp. 315-16). Henry Arthur Jones (1851-1929) was one of the leading British playwrights of the Victorian and Edwardian periods. He had, in fact, met Shaw at William Archer's house on 4 May 1885. Shaw wrote highly respectful, if often incisively critical, reviews of Jones's plays in the Saturday Review, and the friendship between the two survived frequent quarrels before a serious rift over Shaw's attitude towards the First World War (see below, p. 231). Thomas James Wise (1859-1937) was a celebrated bibliographer and Honorary Fellow of Worcester College, Oxford, later exposed as a forger, on a grand scale, of nineteenth-century pamphlets.

T. J. Wise told me a story of the first occasion on which HAJ set eyes on GBS. It was in 1885, at a meeting of the Shelley Society in the Botanical Theatre at University College, Gower Street. My father and Mr Wise were sitting next to one another on the platform, and, after the official speeches had been made, members of the audience were invited to speak. A tall lank figure in grey flannels, with a flaming head and beard, shot up from the middle of the hall and said, 'Ladies and gentlemen, I am an atheist (pause), a vegetarian (pause) and a Socialist (pause)' - Henry Arthur nudged Mr Wise and said, 'Three damned good reasons why he ought to be chucked out.' 